\title{
ION-PLASMA DEPOSITION OF THIN QUASICRYSTALLINE Al-Cu-Fe AND Al-Cu-Co FILMS
}

\author{
S.I. Ryabtsev, O.V. Sukhova \\ The Oles’ Honchar Dnipro National University, Dnipro, Ukraine \\ E-mail: sukhovaya@ukr.net
}

\begin{abstract}
$\mathrm{Al}-\mathrm{Cu}-\mathrm{Fe}$ and $\mathrm{Al}-\mathrm{Co}-\mathrm{Cu}$ thin films were firstly deposited on sodium chloride or glass-ceramic substrates by modernized method of three-electrode ion-plasma sputtering. The nominal compositions of the films were chosen in the regions of quasicrystalline phases formation. The as-sputtered films were typically 85 to $260 \mathrm{~nm}$ thick. The films were annealed at temperatures ranging from 873 to $923 \mathrm{~K}$ for $10 \mathrm{~min} . . .3 \mathrm{~h}$. The structure of films was studied by scanning and transmission electron microscopy and X-ray analysis. Electrical properties were determined by a fourprobe method. The as-deposited $\mathrm{Al}-\mathrm{Cu}-\mathrm{Fe}$ film was found to consist of isolated quasicrystalline nanoparticles of icosahedral $i$-phase. With substitution of $\mathrm{Fe}$ for $\mathrm{Co}$ in $\mathrm{Al}-\mathrm{Co}-\mathrm{Cu}$ film, X-ray amorphous phase and only traces of quasicrystalline decagonal $D$-phase were revealed. After annealing, the films were predominately quasicrystalline due to transformation of metallic phases into quasicrystalline. At the same time, the size of coherent scattering regions for quasicrystals increased by two times from $\sim 3$ to $6 \mathrm{~nm}$. Measurements of electrical resistivity showed that no phase transformations occurred in $\mathrm{Al}-\mathrm{Cu}-\mathrm{Fe}$ film up to $723 \mathrm{~K}$ and in $\mathrm{Al}-\mathrm{Co}-\mathrm{Cu}$ film up to $640 \mathrm{~K}$. With following increase in temperature, electrical resistivity of $\mathrm{Al}-\mathrm{Cu}-\mathrm{Fe}$ film increased by six orders of magnitude (up to $6 \cdot 10^{7} \Omega / \mathrm{sq}$ ). In contrast, electrical resistivity of Al-Co-Cu film decreased by $\sim 2$ times. After cooling to room temperature, resistivity of $\mathrm{Al}-\mathrm{Cu}-\mathrm{Fe}$ film equaled to $\sim 3 \cdot 10^{5} \Omega / \mathrm{sq}$ and that of $\mathrm{Al}-\mathrm{Co}-\mathrm{Cu}$ film - to $8.7 \Omega / \mathrm{sq}$. We concluded that $\mathrm{Al}-\mathrm{Cu}-\mathrm{Fe}$ thin film is more suitable candidate for application as precise high-ohmic materials.
\end{abstract}

PACS: 61.44.Br, 81.15.Fg, 61.43.Dq, 64.60.My, 81.07.Bc, 75.70.-i

\section{INTRODUCTION}

$\mathrm{Al}-\mathrm{Cu}-\mathrm{Fe}$ or $\mathrm{Al}-\mathrm{Cu}-\mathrm{Co}$ alloy systems have been identified as systems in which three-dimensional icosahedral $(i)$ or two-dimensional decagonal $(D)$ quasicrystals are stable at high temperatures [1, 2]. Both systems are known to yield quasicrystalline phases after slow solidification. Discoveries of the stable quasicrystals have inspired a great progress in the studies of quasicrystalline structure and properties. It has been found that these materials have unique mechanical and tribological properties, including low friction, high hardness, high wear, corrosion and oxidation resistance [3-5]. Other properties such as brittleness have hindered the use of quasicrystals in bulk form, although they have shown significant potential for use as thick composite coatings $[6,7]$ and thin films $[8$, 9].

To produce a large variety of thin quasicrystalline $\mathrm{Al}-\mathrm{Cu}-\mathrm{Fe}$ films on $\mathrm{Al}_{2} \mathrm{O}_{3}, \mathrm{MgO}, \mathrm{NaCl}$ etc. substrate materials, the methods of vapor deposition are now used [10]. The films were deposited at various substrate temperatures in either the amorphous or the crystalline state or as a stack of elemental layers [11, 12]. The icosahedral quasicrystalline phase ( $i$-phase) was obtained by subsequent annealing. Thin quasicrystalline $\mathrm{Al}-\mathrm{Cu}-\mathrm{Fe}$ films were also formed directly by such methods as sputtering or evaporation, without need for post-deposition treatments [13]. Due to rapid cooling, quasicrystalline coatings based on $\mathrm{Al}-\mathrm{Cu}-\mathrm{Fe}$ quasicrystals have shown high resistance to wear, corrosion in aqueous solutions, low thermal conductivity [14-18]. They are ideal candidates for applications requiring sliding contact [19-21].

Thin films of Al-Cu-Co alloys were grown by thermal vapour deposition technique by varying the composition of the target material [22]. It was observed that quasicrystalline decagonal phase ( $D$-phase) did not form in thin films when the composition of the target material was close to that of quasicrystalline phase, i.e., $\mathrm{Al}_{65} \mathrm{Cu}_{15} \mathrm{Co}_{20}$. The deposited films of lower thickness $(<200 \mathrm{~nm})$ were always found to contain amorphous phase which transformed mainly to crystalline phases. By several trials of changing the composition of the target material it was found that target alloy composition close to $\mathrm{Al}_{50} \mathrm{Cu}_{20} \mathrm{Co}_{30}$ yielded maximum amount of $\mathrm{Al}_{65} \mathrm{Cu}_{15} \mathrm{Co}_{20}$ quasicrystalline phase in the films of $1000 \ldots 2000 \mathrm{~nm}$ in thickness. The composition variation between the target alloy and the deposited film was explained by significant differences in partial vapour pressure among the constituent elements. The phase evolution under rapid solidification condition of the melt spun $\mathrm{Al}-\mathrm{Cu}-\mathrm{Co}-\mathrm{Ni}$ ribbons may also open an interesting field of applications [23]. The thickness and width of the ribbons were found to be $\sim 50 \mu \mathrm{m}$ and $\sim 0.75 \ldots 1.0 \mathrm{~mm}$, respectively.

Thus, the structure of quasicrystalline coatings has been found to be sensitive to the cooling rate achieved during deposition [24-30]. Therefore, it is essential to monitor the rates of sputtered atoms which have a considerable dispersion not only in magnitude but also in direction. An acceleration of ions impinging on the target and, correspondingly, an increase in their kinetic energy by factors of 5 to 6 can be achieved by using a modernized method of ion-plasma sputtering [31, 32]. This method ensures a more uniform mixing of components upon their deposition on the substrates than traditional techniques [33]. The cooling rates for deposited films, theoretically estimated considering the time of atoms relaxation, are within the range of $10^{13}$ to $10^{14} \mathrm{~K} / \mathrm{s}$. The structure of the films is formed in extra non-equilibrium conditions. 
It may be assumed that quasicrystalline materials appear to be a potential candidate for application as an efficient coating material on various substrates. However, it must be pointed out that in order to obtain a good quality quasicrystalline thin film, there is a need to pursue the study of their formation. Understanding the stages of quasicrystalline film growth is critical to reproducible film fabrication.

The aim of the present work is to deposit stable quasicrystalline thin films of $\mathrm{Al}-\mathrm{Cu}-\mathrm{Fe}$ and $\mathrm{Al}-\mathrm{Cu}-\mathrm{Co}$ alloys grown by the modernized ion-plasma sputtering technique. Coatings prepared of these alloys have been investigated as well for their electrical properties.

\section{MATERIALS AND METHODS}

Thin films were deposited on sodium chloride or glass-ceramic substrates by modernized method of three-electrode ion-plasma sputtering [31]. As targets, $20 \times 20 \times 5 \mathrm{~mm}$ parallelepipeds were used made of pure components (99.99\%). The parallelepipeds were separated by barrier cells performing like electrostatic lens. Details concerning schematic drawing of sputtering system can be found in [32].

The sputtering parameters to deposit quasicrystalline coatings by modernized method of three-electrode ionplasma sputtering are listed in Table, where $P_{\text {start }}$ is starting vacuum in the working chamber; $P_{A r}$ is a pressure of orifice gas (Ar); $U_{M}$ is a target voltage; $I_{A}$ is anode current; $j$ is target current density; $t_{d e p}$ is a time of deposition on substrates; $D$ is a thickness of films deposited on glass-ceramic substrates; $d_{T E M}$ is a thickness of films deposited on sodium chloride substrates for TEM investigation; $\eta$ is a rate of deposition.

Sputtering conditions for thin films

\begin{tabular}{|c|c|c|}
\hline Parameter & $\mathrm{Al}_{60} \mathrm{Cu}_{28} \mathrm{Fe}_{12}$ & $\mathrm{Al}_{66} \mathrm{Cu}_{18} \mathrm{Co}_{16}$ \\
\hline$P_{\text {start }}, \mathrm{mPa}$ & 1.2 & 2.0 \\
\hline$P_{\text {Ar }}, \mathrm{mPa}$ & 53 & 53 \\
\hline$U_{M}, \mathrm{kV}$ & -2 & -2 \\
\hline$I_{A}, \mathrm{~A}$ & 2 & 2 \\
\hline$j, \mathrm{~A} / \mathrm{m}^{2}$ & 4.8 & 6.8 \\
\hline$t_{\text {dep }}, \mathrm{s}$ & $1660 / 120$ & $1440 / 180$ \\
\hline$D, \mathrm{~nm}$ & $260 / 19$ & $105 / 14$ \\
\hline$d_{T E M}, \mathrm{~nm}$ & 19 & 14 \\
\hline$\eta, \mathrm{pm} / \mathrm{s}$ & 160 & 73 \\
\hline
\end{tabular}

The initial compositions of the targets used for sputtering were $\mathrm{Al}_{60} \mathrm{Cu}_{28} \mathrm{Fe}_{12}$ and $\mathrm{Al}_{66} \mathrm{Cu}_{18} \mathrm{Co}_{16}$ (at.\%). The nominal compositions were similar to those of the quasicrystalline alloys reported in [1, 2]. The films thickness was varied from 85 to $260 \mathrm{~nm}$. In addition, thin films were annealed in a tube furnace in vacuum at different temperatures $(873 \ldots 923 \mathrm{~K})$ and times $(10 \min . . .3 \mathrm{~h})$.

The films were characterized by scanning (SEM) and transmission (TEM) electron microscopy (EM) together with energy dispersive (EDX) and X-ray diffraction (XRD) techniques. Before examinations, the sodium chloride substrates were removed by dissolving in water to acquire free standing thin films. Electrical resistivity $\left(R_{S}\right)$ of quasicrystalline films deposited on glass-ceramic substrate was measured with the conventional four-probe method in the temperature range $293 \ldots 923 \mathrm{~K}$ at heating rate of $18 \mathrm{~K} / \mathrm{min}$ in vacuum $(\sim 1.3 \mathrm{mPa})$.

\section{RESULTS AND DISCUSSION}

Thin films of $\mathrm{Al}-\mathrm{Cu}-\mathrm{Fe}$ and $\mathrm{Al}-\mathrm{Cu}-\mathrm{Co}$ alloys adhere very well to the substrates and can withstand small plastic strains without failing. EDX measurements show that $\mathrm{Al}-\mathrm{Cu}-\mathrm{Fe}$ films growth reduces the $\mathrm{Al}$ present in the films, but $\mathrm{Cu}$ and $\mathrm{Fe}$ content is close to expected [17]. The average oxygen content is less than 13 at.\%. In the deposited $\mathrm{Al}-\mathrm{Cu}-\mathrm{Co}$ film the $\mathrm{Al}$ content is higher, but the Co content is lower compared to calculated one demonstrating that the rate of Co deposition is lower than that of $\mathrm{Al}$ and $\mathrm{Cu}$ [22]. Composition of the films varies only slightly over the rather large substrate area.

The Al-Cu-Fe film consists of isolated quasicrystalline nanoparticles at the given composition and deposition conditions. The dispersed structure of $\mathrm{Al}-\mathrm{Cu}-\mathrm{Fe}$ film is deduced from EM patterns (Fig. 1). In electron microdiffraction pattern (see Fig. 1,b), the diffraction lines are diffused. No separate reflections are observed here in microdiffraction mode. This confirms the formation of nanosized quasicrystalline particles which takes place by a direct nucleation process.
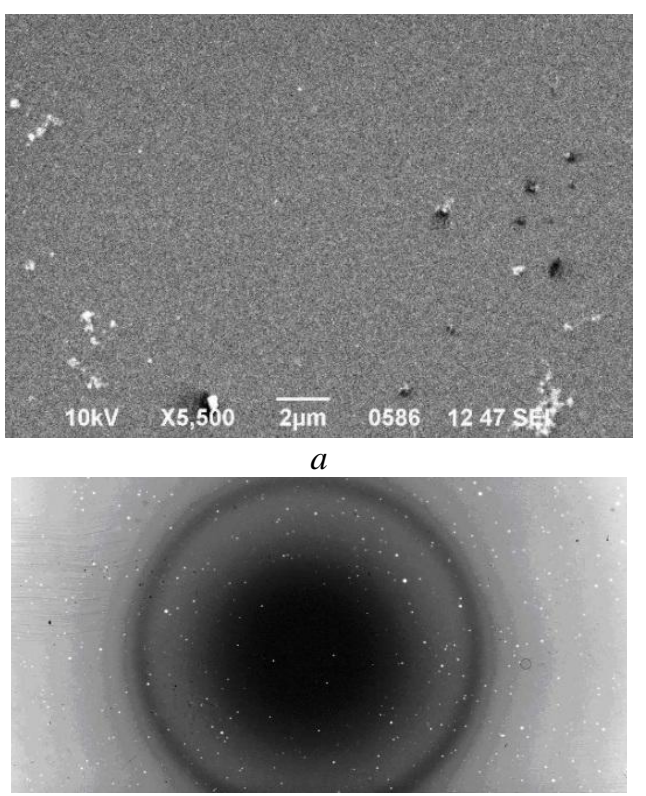

$b$

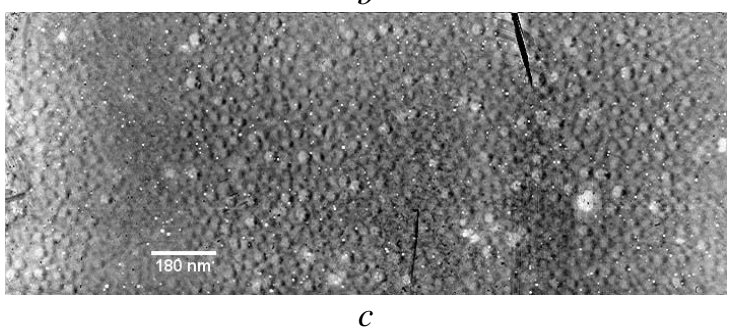

Fig. 1. EM patterns of as-sputtered Al-Cu-Fe film:

$$
\begin{gathered}
a-S E M\left(D \sim 260 \mathrm{~nm}, \times 5.5 \cdot 10^{3}\right) ; \\
b-\text { electron microdiffraction pattern; } \\
c-\text { TEM }\left(d_{T E M} \sim 19 \mathrm{~nm}, \times 4 \cdot 10^{4}\right)
\end{gathered}
$$

XRD pattern also reveals that $\mathrm{Al}-\mathrm{Cu}-\mathrm{Fe}$ film is not continuous but consisted of isolated nanoparticles (Fig. 2,a). The peaks angles are close to those indicated 
for the icosahedral quasicrystalline phase [14]. Nanosize of $i$-phase is verified by a width of diffraction peaks. The size of coherent scattering regions for as-sputtered $\mathrm{Al}-\mathrm{Cu}-\mathrm{Fe}$ film is $\sim 3 \mathrm{~nm}$. The regions surrounding $i$ phases are dispersed crystalline and very thin compared to the quasicrystalline grains.

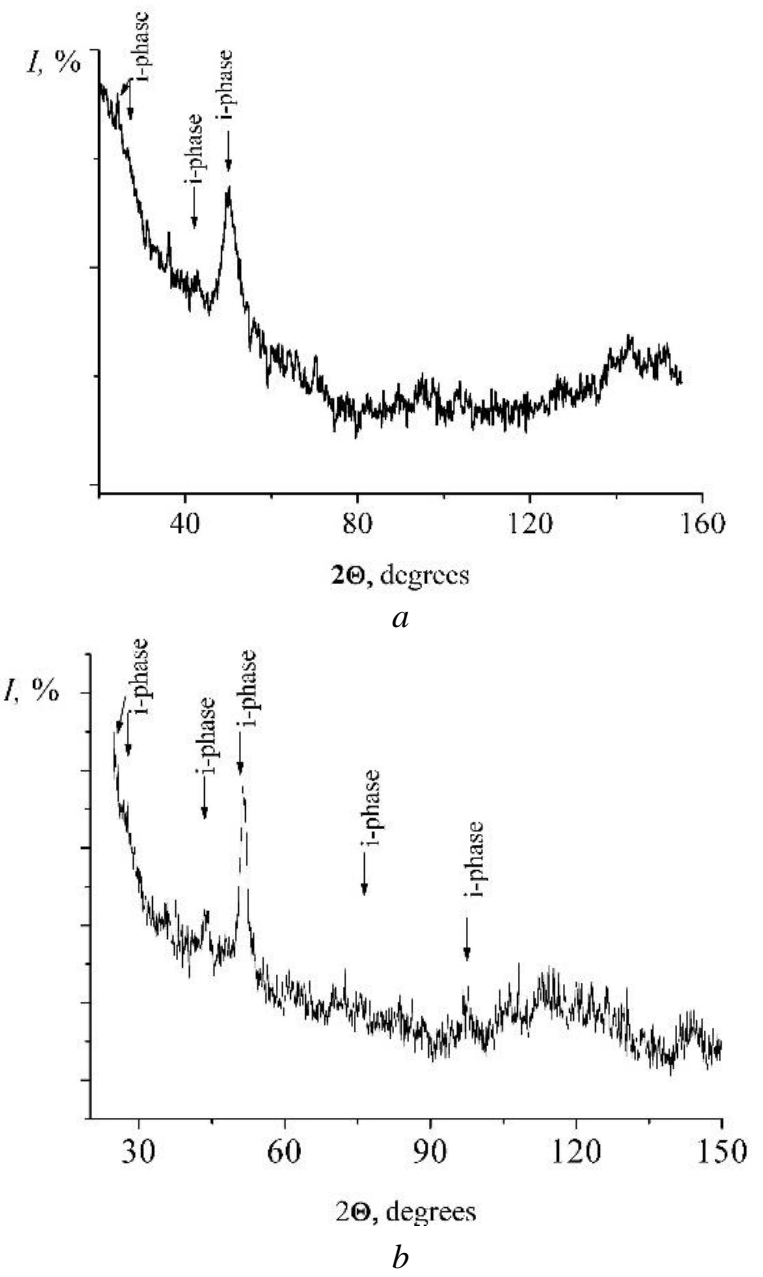

Fig. 2. X-ray patterns of Al-Cu-Fe films: $a$-before annealing, $b$-after annealing

After annealing for $3 \mathrm{~h}$ at $873 \mathrm{~K}$, the $\mathrm{Al}-\mathrm{Cu}-\mathrm{Fe}$ film exhibits coarser structure. Post-annealing treatment reveals that coherent scattering regions of quasicrystalline icosahedral phase become $\sim 6 \mathrm{~nm}$ in size. So, a twofold increase in size is observed as compared to that of as-sputtered film. In X-ray pattern additional diffraction peaks appear after annealing (see Fig. 2,b). All the peaks can be identified as icosahedral single phase. Diffraction peaks become narrow; their intensity increases. In addition, most of the peak positions are shifted towards lower angles because of the effect of thermal relaxation and volume diffusion of components in the films.

In the heating procedure with a rate of $18 \mathrm{~K} / \mathrm{min}$, measurements of electrical resistivity $\left(R_{S}\right)$ show that the $\mathrm{Al}-\mathrm{Cu}-\mathrm{Fe}$ film is stable up to $723 \mathrm{~K}$. Over a temperature range of $293 \ldots 723 \mathrm{~K}$, the slight reversible decrease in a resistivity from 20 to $19.9 \Omega / \mathrm{sq}$ is observed which indicates that no phase transformations take place (Fig. 3). The temperature coefficient of the resistivity (TCR) is of negative value $-2 \cdot 10^{-4} \mathrm{~K}^{-1}$. As the temperature is raised from 723 to $803 \mathrm{~K}$, irreversible increase in electrical resistivity by six orders of magnitude (up to $6 \cdot 10^{7} \Omega / \mathrm{sq}$ ) evidences that the structure of the $\mathrm{Al}-\mathrm{Cu}-\mathrm{Fe}$ film starts changing. Activation energy of phase transformations calculated using Kissinger method equals to $\sim 103 \mathrm{KJ} / \mathrm{mol}$. With following increase in temperature up to $873 \mathrm{~K}, R_{S}$ slightly decreases with the negative temperature coefficient of the resistivity. In cooling up to $753 \mathrm{~K}$ electrical resistivity decreases up to $\sim 3 \cdot 10^{5} \Omega /$ sq. Then, in cooling up to room temperature, it slightly lowers with the negative TCR amounting to $\sim-5 \cdot 10^{-6} \mathrm{~K}^{-1}$. The observed changes in electrical resistivity of the deposits during heating are consistent with the above described changes of their nanoquasicrystalline structure. The presence of the three-dimensional quasi-periodicity contributes to the sharp increase in the electrical resistivity which can be explained by the specific properties of icosahedral quasicrystals [34].

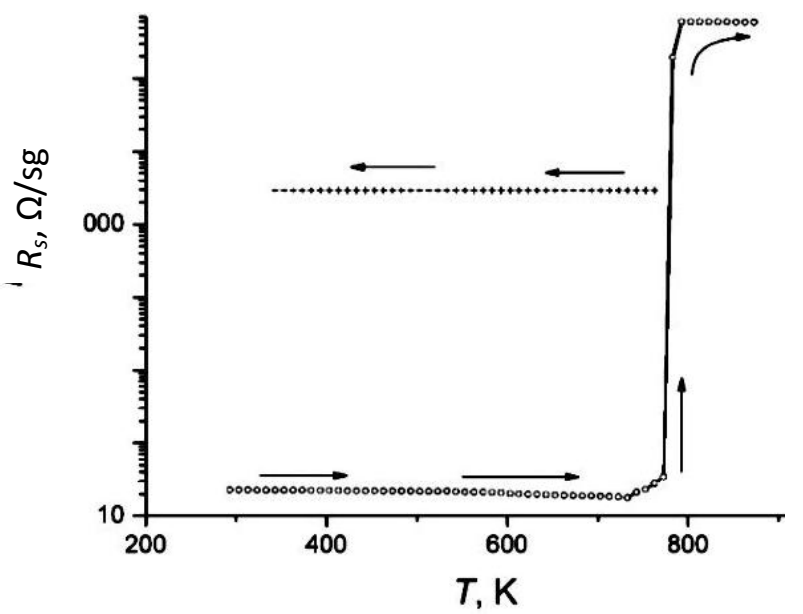

Fig. 3. Temperature dependence of electrical resistivity of Al-Cu-Fe film at heating rate of $18 \mathrm{~K} / \mathrm{min}$

As-sputtered Al-Cu-Co film is found to consist of $\mathrm{X}$-ray amorphous phase. Some traces of quasicrystalline $D$-phase are revealed as well. The presence of these phases is verified by XRD (Fig. 4,a). The size of coherent scattering regions for $D$-phase is $\sim 2.8 \mathrm{~nm}$.

After annealing for $10 \mathrm{~min}$ at $923 \mathrm{~K}$, the $\mathrm{Al}-\mathrm{Cu}-\mathrm{Co}$ film consists of a decagonal phase and an Al-based crystalline phase. This can be explained as follows. Enhanced diffusion leads to the rapid growth of quasicrystalline phases resulting in the expulsion of mainly aluminum to the surrounding matrix. Diffraction pattern from the decagonal phase and Al-based phase of post-annealed Al-Cu-Co film is shown in Fig. 4,b. Stresses relaxation and disappearance of amorphous phase may also be responsible for narrowing of some reflections in XRD pattern. In addition, due to solid state diffusion the significant shift in positions of diffraction peaks is revealed.

Annealing experiments show coarsening behavior. The coherent scattering regions for $D$-phase increase in size up to $6 \mathrm{~nm}$ after annealing. Thus, as-sputtered Al$\mathrm{Cu}-\mathrm{Co}$ thin film has mainly an amorphous structure. This amorphous phase is metastable and transforms to a mixture of quasicrystalline and crystalline phases upon short annealing. At temperature $923 \mathrm{~K}$, diffusion is highly enhanced and results in a twofold enlargement of coherent scattering regions for $D$-phase. 


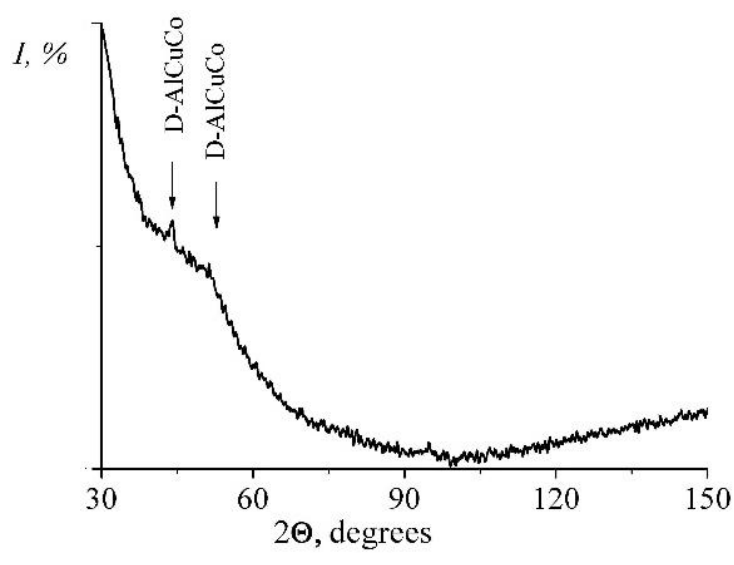

$a$

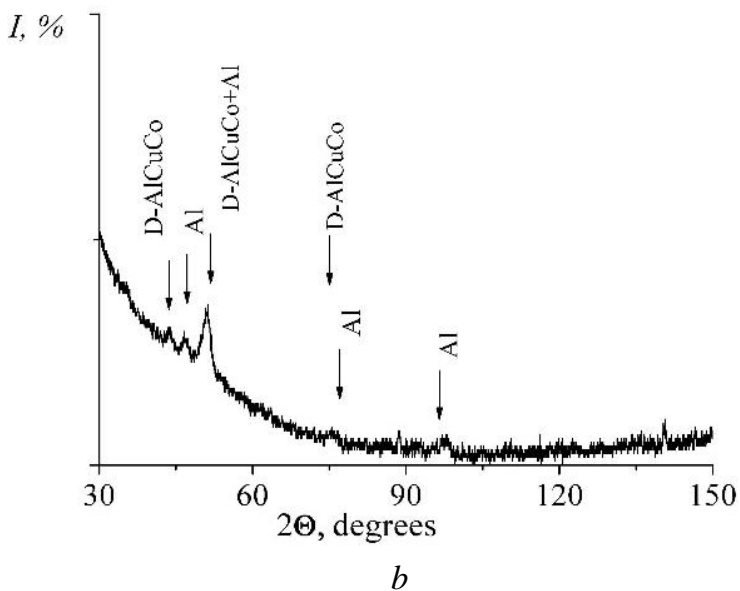

Fig. 4. X-ray patterns of Al-Cu-Co films: $a$-before annealing, $b$-after annealing

The as-sputtered $\mathrm{Al}-\mathrm{Cu}-\mathrm{Co}$ thin film has relatively small values of electrical resistivity amounting to $\sim 22 . .25 \Omega /$ sq (Fig. 5). Such values may be explained by the presence of amorphous phase with the positive temperature coefficient of the resistivity in the film. During heating, TCR for quasicrystalline and crystalline phases may mutually compensate each other. Investigations of electrical properties over a temperature range of $290 \ldots 640 \mathrm{~K}$ reveal that electrical resistivity shows reversible change from $\sim 22$ to $\sim 21.8 \Omega /$ sq. This means that structure of the film remains unchanged. The temperature coefficient of the resistivity for $\mathrm{Al}-\mathrm{Cu}-\mathrm{Co}$ film is negative and equals to $-6 \cdot 10^{-4} \mathrm{~K}^{-1}$.

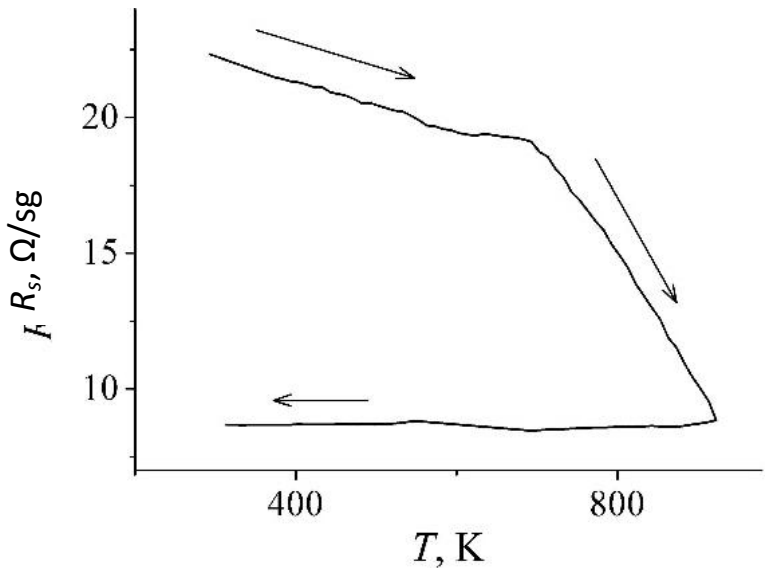

Fig. 5. Temperature dependence of electrical resistivity of Al-Cu-Co film at heating rate of $18 \mathrm{~K} / \mathrm{min}$
In a temperature range of $640 \ldots 920 \mathrm{~K}$, irreversible change of $R_{S}$ from 19.3 to $8.8 \Omega / \mathrm{sq}$ is observed which indicates a start of phase transformations inducing structural changes. As annealing experiments show, this may be related to transformation from amorphous phase to a mixture of quasicrystalline and crystalline phases. Activation energy of structural changes reaches $\sim 51 \mathrm{KJ} / \mathrm{mol}$. In the cooling from $920 \mathrm{~K}$ to room temperature, resistivity for $\mathrm{Al}-\mathrm{Cu}-\mathrm{Co}$ film decreases up to $8.7 \Omega / \mathrm{sq}$ and TCR amounts to $-1.2 \cdot 10^{-5} \mathrm{~K}^{-1}$. The revealed difference in the electrical resistivity of $\mathrm{Al}-\mathrm{Cu}-$ $\mathrm{Co}$ and $\mathrm{Al}-\mathrm{Cu}-\mathrm{Fe}$ thin films originates from differences both in their atomic arrangements and the accompanying electronic structure [34].

\section{CONCLUSIONS}

The quasicrystalline $\mathrm{Al}-\mathrm{Cu}-\mathrm{Fe}$ and $\mathrm{Al}-\mathrm{Cu}-\mathrm{Co}$ thin films have been first deposited by modernized method of three-electrode ion-plasma sputtering on $\mathrm{NaCl}$ or glass-ceramic substrates at cooling rates of $10^{13} \ldots 10^{14} \mathrm{~K} / \mathrm{s}$.

In the case of $\mathrm{Al}-\mathrm{Cu}-\mathrm{Fe}$ film, an almost pure icosahedral quasicrystalline $i$-phase can be obtained. Determination of a size of coherent scattering regions indicates that the $i$-phase of the $\mathrm{Al}-\mathrm{Cu}-\mathrm{Fe}$ film is in nanostructural state. Post-annealing treatment for $3 \mathrm{~h}$ at $873 \mathrm{~K}$ reveals an increase in the amount of $i$-phase and a twofold increase of the size of its coherent scattering regions due to solid state diffusion. The measurements of an electrical resistivity of the depositions show that the $\mathrm{Al}-\mathrm{Cu}-\mathrm{Fe}$ film is stable up to the temperature of $723 \mathrm{~K}$. In a temperature range of 723 to $773 \mathrm{~K}$, its electrical resistivity increases by six orders of magnitude. The Al-Cu-Fe film exhibits a negative temperature dependence of resistivity over a wide temperature range.

In the deposited $\mathrm{Al}-\mathrm{Cu}-\mathrm{Co}$ film, X-ray amorphous phase and traces of decagonal quasicrystalline $D$-phase are revealed. At annealing temperature of $923 \mathrm{~K}$, transformation from amorphous phase to a mixture of decagonal quasicrystalline and Al-based crystalline phases is observed. Annealing results in almost twice larger coherent scattering regions of $D$-phase. As electrical resistivity measurements evidence, $\mathrm{Al}-\mathrm{Cu}-\mathrm{Co}$ film is stable up to $640 \mathrm{~K}$. During cooling from $920 \mathrm{~K}$ to room temperature, the negative temperature coefficient of the resistivity changes as compared with that of the as-sputtered film.

Thus, by controlling the process parameters such as the deposition rate, thickness, substrate temperature, the composition as well as annealing procedure, it may be possible to obtain quasicrystalline $\mathrm{Al}-\mathrm{Cu}-\mathrm{Fe}$ and $\mathrm{Al}-\mathrm{Cu}-$ Co films. The three-dimensional icosahedral quasicrystals possess much higher electrical resistivity than the two-dimensional decagonal quasicrystals. This leads us to conclude that the quasicrystalline $\mathrm{Al}-\mathrm{Cu}-\mathrm{Fe}$ thin film is more suitable candidate for fabrication of precise high ohmic resistors.

\section{REFERENCES}

1. F. Faudot, A. Quivy, Y. Calvayrac, D. Gratias, M. Harmelin. About the Al-Cu-Fe icosahedral phase 
formation // Materials Science and Engineering. 1991, v. A133, p. 383-387.

2. A.-P. Tsai, A. Inoue, T. Masumoto. A stable decagonal quasicrystal in the Al-Cu-Co system // Materials Transactions. 1989, v. 30(4), p. 300-304.

3. Z.M. Stadnik. Physical Properties of Quasicrystals. Berlin: "Springer-Verlag", 1999, 438 p.

4. O.V. Sukhova, V.A. Polonskyy, K.V. Ustinova. Corrosion resistance of alloys of the Al-Cu-Fe-( $\mathrm{Si}, \mathrm{B})$ system in mineralized saline and acid solutions // Materials Science. 2019, v. 55(2), p. 285-292.

5. O.V. Sukhova, V.A. Polonskyy, K.V. Ustinova. The influence of $\mathrm{Si}$ and $\mathrm{B}$ on the structure and corrosion properties of quasicrystal $\mathrm{Al}-\mathrm{Cu}-\mathrm{Fe}$ alloys in saline solutions // Metallofizika and Noveishie Technologii. 2018, v. 40(11), p. 1475-1487.

6. O.V. Sukhova. Influence of mechanisms of structure formation of interfaces in composites on their properties // Metallofizika and Noveishie Technologii. 2009, v. 31(7), p. 1001-1012 (in Russian).

7. O.V. Sukhova, Yu.V. Syrovatko. Features of structurization of composite materials of the solutionand-diffusion type // Metallofizika i Noveishie Tekhnologii. 2011, v. 33, p. 371-378 (in Russian).

8. J.-M. Dubois, S.S. Kang, Y. Massiani. Application of quasicrystalline alloys to surface coating of soft metals // Journal of Non-Crystalline Solids. 1993, N 153-154, p. 443-445.

9. I.M. Spyrydonova, O.V. Sukhova, G.V. Zinkovskij. Thin films and composites based on quasicrystal $\mathrm{Al}-\mathrm{Cu}-\mathrm{Fe}$ alloy // Metallurgical and Mining Industry. 2012, v. 4(4), p. 2-5.

10. D.S. Shaitura, A.A. Enaleeva. Fabrication of quasicrystalline coatings: a review // Crystallography Reports. 2007, v. 52(6), p. 945-952.

11. T. Eisenhammer, A. Trampert. Formation of quasicrystalline $\mathrm{AlCuFe}$ by physical vapor deposition: phase selection via nanocluster nucleation // Physical Review Letters. 1997, v. 78(2), p. 262-265.

12. S. Olsson, F. Eriksson, J. Birch, L. Hultman. Formation of $\alpha$-approximant and quasicrystalline $\mathrm{Al}-\mathrm{Cu}$ Fe thin films // Thin Solid Films. 2012, v. 526, p. 74-80.

13. E.J. Widjaja, L.D. Marks. In situ studies of magnetron sputtered $\mathrm{Al}-\mathrm{Cu}-\mathrm{Fe}-\mathrm{Cr}$ quasicrystalline thin films // Thin Solid Films. 2002, N 420-421, p. 295-299.

14. J.E. Shield, J.A. Campbell, D.J. Sordelet. Mechanical properties of $\mathrm{Al}-\mathrm{Cu}-\mathrm{Fe}$ based quasicrystalline coatings // Journal of Materials Science Letters. 1997, N 16, p. 2019-2021.

15. C. Zhou, R. Cai, S. Gong, H. Xu. Hot corrosion of $\mathrm{AlCuFeCr}$ quasicrystalline coating on titanium alloys with $\mathrm{NaCl}$ deposit//Surface and Coatings Technology. 2006, N 201, p. 1718-1723.

16. B.S. Phillips, J.S. Zabinski. Steam and water lubrication of quasicrystalline films // Tribology Letters. 2004, v. 17(3), p. 429-434.

17. S.I. Ryabtsev, V.A. Polonskyy, O.V. Sukhova. Effect of scandium on the structure and corrosion properties of vapor-deposited nanostructural quasicrystalline Al-Cu-Fe films // Powder Metallurgy and Metal Ceramics. 2019, v. 58(9-10), p. 567-575.

18. O.V. Sukhova, V.A. Polonskyy, K.V. Ustinova. Microstructure and corrosion properties of quasicrystal $\mathrm{Al}-\mathrm{Cu}-\mathrm{Fe}$ alloys alloyed with $\mathrm{Si}$ and $\mathrm{B}$ in acidic solutions // Voprosy Khimii $i \quad$ Khimicheskoi Tekhnologii. 2018, v. 6(121), p. 77-83 (in Russian).

19. D.M. Rampulla, C.M. Mancinelli, I.F. Brunell, A.J. Gellman. Oxidative and tribological properties of amorphous and quasicrystalline approximant $\mathrm{Al}-\mathrm{Cu}-\mathrm{Fe}$ thin films // Langmuir. 2005, N 6, p. 4547-4553.

20. R.P. Matthews, C.I. Lang, D. Shechtman. Sliding wear of quasicrystalline coatings // Tribology Letters. 1999, N 7, p. 179-181.

21. S.S. Kang, J.M. Dubois, J. Stebut. Tribolo-gical properties of quasicrystalline coatings // Journal of Materials Research. 1993, v. 8(10), p. 2471-2481.

22. N.K. Mukhopadhyaya, G.C. Weatherly. Formation of quasicrystalline and vacancy ordered phases in vapour deposited thin films of $\mathrm{Al}-\mathrm{Cu}-\mathrm{Co}$ alloys // Materials Science and Engineering. 2001, v. A304-306, p. 855-859.

23. T.P. Yadav, N.K. Mukhopadhyay, R.S. Tiwari, O.N. Srivastava. On the evolution of quasicrystalline and crystalline phases in rapidly quenched $\mathrm{Al}-\mathrm{Cu}-\mathrm{Co}-\mathrm{Ni}$ alloy // Materials Science and Engineering. 2007, v. A449-451, p. 1052-1056.

24. I. Yamauchi, O. Ohmori, I. Ohnaka. Metastable phase formation by chemical leaching of $\mathrm{Al}-\mathrm{Cu}-\mathrm{Co}$ ternary alloys // Journal of Alloys and Compounds. 2000, v. 299, p. 269-275.

25. I. Yamauchi, O. Ohmori, I. Ohnaka. Rapid solidification and mechanical alloying of $\mathrm{Al}-\mathrm{Cu}-\mathrm{Co}$ ternary alloys for chemical leaching // Journal of Alloys and Compounds. 2000, v. 299, p. 276-282.

26. V.C. Srivastava, V.U. Unlenwinkel, A. Schulz, H.-W. Zoch, N.K. Mukhopadhyay, S.G. Chowdhury. Synthesis of single phase i-AlCuFe bulk quasicrystal by spray forming // Crystalline Materials. 2008, v. 223, p. 711-715.

27. I.M. Spiridonova, E.V. Sukhovaya, V.P. Balakin. Structure and deformation peculiarities of $\mathrm{Fe}(\mathrm{B}, \mathrm{C})$ crystals // Metallurgy. 1996, v. 35(2), p. 65-68.

28. D.J. Sordelet, M.J. Kramer, O. Unal. Effect of starting powders on the control of microstructural development of $\mathrm{Al}-\mathrm{Cu}-\mathrm{Fe}$ quasi-crystalline plasmasprayed coatings // Journal of Thermal Spray Technology. 1995, v. 4(3), p. 235-244.

29. I.M. Spiridonova, E.V. Sukhovaya, V.F. Butenko, A.P. Zhudra, A.I. Litvinenko, A.I. Belyi. Structure and properties of boron-bearing iron granules for composites // Powder Metallurgy and Metal Ceramics. 1993, N 2, p. 45-49.

30. O.V. Sukhova, K.V. Ustinova. The effect of cooling rate on phase composition of quasicrystalline $\mathrm{Al}-\mathrm{Cu}-\mathrm{Fe}$ alloys doped with $\mathrm{Si}$ and $\mathrm{B} / /$ Functional Materials. 2019, v. 26(3), p. 495-506.

31. S.I. Ryabtsev. Structure and properties of ionplasma-deposited films of $\mathrm{Fe}-(\mathrm{Ag}, \mathrm{Bi})$ alloys // Physics of Metals and Metallography. 2009, v. 108(3), p. 226-231.

32. V.F. Bashev, F.F. Dotshenko, I.S. Miroshnichenko, V.H. Pasalsky. Structure and electrical properties of $\mathrm{Ag}-\mathrm{W}$ films in metastable states // The 
Physics of Metals and Metallography. 1992, v. 73(2), p. 152-156.

33. V.G. Efremenko, K. Shimizu, T.V. Pastukhova, Yu.G. Chabak, K. Kusumoto, A.V. Efremenko. Effect of bulk heat treatment and plasma surface hardening on the microstructure and erosion wear resistance of complex-alloyed cast irons with spheroidal vanadium carbides // Journal of Friction and Wear. 2017, v. 38(1), p. 58-64.

34. T. Takeuchi, U. Mizutani. Interpretation of high electrical resistivity behavior based on the structure determination of the $\mathrm{Al}-\mathrm{Cu}-(\mathrm{Fe}, \mathrm{Ru})-\mathrm{Si}$ 1/1-cubic approximants // Journal of Alloys and Compounds. 2002, v. 342, p. 416-421.

Article received 26.12.2019

\title{
ОСАЖДЕНИЕ ТОНКИХ КВАЗИКРИСТАЛЛИЧЕСКИХ ПЛЕНОК Аl-Cu-Fe И Al-Cu-Co ИОННО-ПЛАЗМЕННЫМ МЕТОДОМ
}

\author{
С.И. Рябцев, Е.В. Суховая
}

Тонкие пленки Al-Cu-Fe и Al-Co-Cu были впервые нанесены на подложки из натрий хлорида и ситала модернизированным методом трехэлектродного ионно-плазменного осаждения. Номинальные составы пленок выбирали в области существования квазикристаллических фаз. Толщина напыленных пленок составляла от 85 до 260 нм. Пленки отжигали в интервале температур 873...923 К в течение 10 мин...3 ч. Структуру пленок изучали методами сканирующей и трансмиссионной электронной микроскопии и рентгеноструктурного анализа. Электрические свойства определяли четырехзондовым методом. Установлено, что в свеженапыленном состоянии пленка $\mathrm{Al}-\mathrm{Cu}-\mathrm{Fe}$ состоит из изолированных квазикристаллических наночастиц икосаэдрической $i$-фазы. При замене $\mathrm{Fe}$ на Co в пленке $\mathrm{Al}-\mathrm{Co}-\mathrm{Cu}$ обнаружены рентгеноаморфная фаза и следы квазикристаллической декагональной $D$-фазы. После отжига пленки имеют преимущественно квазикристаллическую структуру вследствие превращения металлических фаз в квазикристаллические. При этом размер областей когерентного рассеяния квазикристаллов увеличивается в два раза с 3 до 6 нм. Измерения электрического сопротивления показали, что в пленке Al$\mathrm{Cu}-\mathrm{Fe}$ отсутствуют фазовые превращения вплоть до температуры $723 \mathrm{~K}$, а в пленке Al-Co-Cu - до $640 \mathrm{~K}$. При последующем нагреве электрическое сопротивление пленки $\mathrm{Al}-\mathrm{Cu}-\mathrm{Fe}$ возрастает на шесть порядков (до $6 \cdot 10^{7}$ Ом/кв). Напротив, электрическое сопротивление пленки Al-Co-Cu уменьшается в 2 раза. После охлаждения до комнатной температуры сопротивление пленки $\mathrm{Al}-\mathrm{Cu}-\mathrm{Fe}$ составляет 3·10 5 Ом/кв, а пленки $\mathrm{Al}-\mathrm{Co}-\mathrm{Cu}-8,7$ Oм/кв. Сделан вывод о том, что пленка Al-Cu-Fe является более перспективным материалом для изготовления прецизионных высокоомных резисторов.

\section{ОСАДЖЕННЯ ТОНКИХ КВАЗІКРИСТАЛІЧНИХ ПЛІВОК Al-Cu-Fe TA Al-Cu-Co ІОННО-ПЛАЗМОВИМ МЕТОДОМ}

\section{С.I. Рябцев, О.В. Сухова}

Тонкі плівки $\mathrm{Al}-\mathrm{Cu}-\mathrm{Fe}$ та $\mathrm{Al}-\mathrm{Co}-\mathrm{Cu}$ були вперше нанесені на підкладки з натрій хлориду та сіталу модернізованим методом триелектродного іонно-плазмового осадження. Номінальний склад плівок обирали в області існування квазікристалічних фаз. Товщина напилених плівок складала від 85 до 260 нм. Плівки відпалювали в інтервалі температур $873 \ldots 923 \mathrm{~K}$ на протязі 10 хв...3 год. Структуру плівок вивчали методами скануючої і трансмісійної електронної мікроскопії та рентгеноструктурного аналізу. Електричні властивості визначали чотиризондовим методом. Встановлено, що в свіжонапиленому стані плівка $\mathrm{Al}-\mathrm{Cu}-\mathrm{Fe}$ складається з ізольованих квазікристалічних наночастинок ікосаедричної $i$-фази. У разі заміни $\mathrm{Fe}$ на Со в плівці Al-Co-Cu виявлені рентгеноаморфна фаза і сліди квазікристалічної декагональної $D$-фази. Після відпалу плівки мають переважно квазікристалічну структуру внаслідок перетворення металевих фаз на квазікристалічні. При цьому розмір областей когерентного розсіювання квазікристалів збільшується в два рази з 3 до 6 нм. Виміри електричного опору показали, що в плівці Al-Cu-Fe відсутні фазові перетворення аж до температури $723 \mathrm{~K}$, а в плівці Al-Co-Cu - до 640 К. Під час наступного нагріву електричний опір плівки Al-Cu-Fe збільшується на шість порядків (до 6·107 Ом/кв). Навпаки, електричний опір плівки Al-Co$\mathrm{Cu}$ зменшується в 2 рази. Після охолодження до кімнатної температури опір плівки $\mathrm{Al}-\mathrm{Cu}-\mathrm{Fe}$ складає $\sim 3 \cdot 10^{5} \mathrm{OM} /$ кв, а плівки Al-Co-Cu $-8,7$ Ом/кв. Зроблено висновок, що плівка Al-Cu-Fe $\epsilon$ більш перспективним матеріалом для виготовлення прецизійних високоомних резисторів. 